Journal of Bangladesh Academy of Sciences, Vol. 37, No. 1, 21-31, 2013

\title{
EFFECTS OF FROZEN STORAGE, RADIATION AND THEIR COMBINED TREATMENTS ON MICROORGANISMS OF FRESHWATER MOLA FISH AMBLYPHARYNGODON MOLA
}

\author{
MD. MANSURUL HAQUE* ${ }^{*}$ M. G. SORROWAR AND HARUN-UR- RASHID ${ }^{1}$ \\ Department of Zoology, Jahangirnagar University, Savar, Dhaka-1342, Bangladesh
}

\begin{abstract}
The study revealed that the total viable bacterial count, staphylococcal count, coliform count, faecal coliform count, Aeromonas count and total fungal counts varied from $8.8 \times 10^{7}$ to $1.27 \times 10^{8}$, $2.7 \times 10^{6}$ to $4.2 \times 10^{6}, 9.0 \times 10^{4}$ to $1.03 \times 10^{5}, 4.810^{5}$ to $7.3 \times 10^{5}, 2.7 \times 10^{5}$ to $5.0 \times 10^{5}$ and $1.6 \times$ $10^{3}$ to $3.5 \times 10^{3} \mathrm{cfu} / \mathrm{gm}$, respectively. Seventy six bacterial strains were isolated and identified, where Staphylococcus aureus, Micrococcus varians, Aeromonas hydrophila, Klebsiella ozaenae, Bacillus subtilis, Escherichia coli, Bacillus megaterium, Klebsiella edwardsii, Pseudomonas aerugenosa and Micrococcus radiodurans were 16 (21.06\%), 11 (14.47\%), 9 (11.82\%), 6 (7.89\%), $6(7.89 \%), 8(10.53 \%), 6(7.89 \%), 4(5.26 \%), 7(9.21 \%)$ and $3(3.95 \%)$, respectively. Total coliform, faecal coliform, Aeromonas bacteria and total fungi were found to be totally inactivated by the irradiation dose of $2.5 \mathrm{kGy}$ onwards and total viable bacteria and staphylococcal bacteria were eliminated completely at the irradiation dose of $7.5 \mathrm{kGy}$. The bacterial counts were shown to be gradually decreased in all the samples from initial to final storage. The combined treatments were found more effective than that of the single treatment for reducing or eliminating the associated bacteria. The moisture contents of the studied fish were found nearly similar during initial and final storage periods and also at different radiation doses but the total protein contents decreased during final storage period and also at different radiation doses.
\end{abstract}

Key words : Mola fish, Coliform, Microorganisms, Radiation treatment, Frozen storage

\section{INTRODUCTION}

Fish is highly nutritious but very perishable that cannot be kept for a long time without any treatment for further consumption. Spoilage is the result of a series of complicated changes brought about in the dead fish mainly by enzymes and bacteria (Dyer 1942). Immediately after the fish dies, certain irreversible changes begin to take place. Within a few hours or more, the muscles gradually harden along the fish until it is quite stiff. The fish can remain rigid for a number of hours or a few days depending in various factors. The muscles then soften or become pliable again. This stiffening is known rigor mortis and is brought about by enzymes in the muscles (Hobbs 1982). Fish is more susceptible to autolysis, oxidation and hydrolysis of fats and microbial spoilage

\footnotetext{
* Corresponding author: <mansurulju@yahoo.com>.

${ }^{1}$ Microbiology and Industrial Irradiation Division, Institute of Food and Radiation Biology, Atomic Energy Research Establishment, Savar, Dhaka-1000, Bangladesh.
} 
(Fraziar and Westhoff 1988). The deterioration is believed to be caused mainly by the bacterial activity, which brings about very noticeable changes in the texture, flavor, odor and general appearance of the product. The microorganisms present in fish include those which are associated with the raw material and acquired during harvesting, handling and processing (Banwart 1979). Mola fishes (Amblypharyngodon mola) are small freshwater indigenous fishes containing more nutrients which are cheaper and easily available in the fish markets. The protein content in mola fish is 15\% (Rubbi et al. 1987). They inhabit in the rivers, canals, beels, ponds haor, baor and inundated floodplains throughout Bangladesh (Rahman 2005). They generally eat algae, protozoa, aquatic insects, rotifers and crustaceans (Rahman 2005). Microorganisms differ in their responses to freezing, some survive virtually unharmed, some resist freezing but are susceptible to damage during frozen storage. Gram-negative organisms such as Escherichia, Pseudomonas, Alcaligenes, Vibrio and Salmonella are more sensitive to freezing than Gram-positive organisms (Thomson and Thacker 1973). Hitherto there is no enough data regarding preservation of mola fish by radiation, low temperature and their combined treatments.

The present study was carried out to oversee the effectiveness of frozen storage, radiation and their combined treatment in the stated fish which would be an effective means of increasing the shelf life of that fish and other fishes as well.

\section{MATERIALS AND METHODS}

The fishes were collected from various fish markets of Savar and Nabinagar. All the samples were aseptically packed in pre-sterilized polythene bags supplied from the Laboratory of Microbiology and Industrial Irradiation Division (MIID), IFRB, AERE. The polythene bags were sealed air tight after collecting the samples. The samples were immediately transported to the laboratory in chilled condition (in insulating foam box with ice) for microbiological analysis. Around 80 polythene bags were prepared and they were sealed properly with the help of sealer machine. Then they were irradiated in the Gamma Irradiation Laboratory to make them aseptic. For six-month-sampling, six sets of polythene bags were prepared. In each polythene bag 200 gram sample was taken. The plate count was performed following the method of Sharp and Lyles (1969). The media used were nutrient agar (pH 7.0 - 7.4), MacConkey agar, mFC agar, staphylococcal agar, potato dextrose and starch ampicillin agar media for total viable bacterial count (TVBC), total viable coliform count (TCC), total faecal coliform count (TFCC), total staphylococcal count (TSC), total fungal count (TFC) and total Aeromonas count (TAC), respectively. Plates were incubated at $37^{\circ} \mathrm{C}$ for $24 \mathrm{hrs}$ and the count was expressed as colony forming unit per gram. Various morphological characteristics were observed and biochemical tests were performed for the isolation and identification of microorganisms. All the bacterial isolates were identified according to the Bergey's Manual of Determinative Bacteriology (1974). For fungal count, the plates were incubated at $28^{\circ} \mathrm{C}$ 
and counts were recorded after 5 days of incubation. For determination of the moisture content of the sample porcelain made crucible was heated at $105^{\circ} \mathrm{C}$ for $1 \mathrm{hr}$ and then kept at desiccators until the crucible reached at room temperature, $4 \mathrm{gm}$ of sample was taken in the crucible and dried at $105^{\circ} \mathrm{C}$ for $3 \mathrm{hrs}$. Then the sample was taken at desiccators until it reached at room temperature and weight of the sample was taken. The process was continued until constant weight was obtained. The loss of moisture from the sample was then determined and expressed in percentage using the following formula.

$$
\text { Moisture content }(\%)=\frac{\text { Initial weight }- \text { Final weight }(\text { i.e. } \text { weight loss })}{\text { Original weight of the sample }} \times 100
$$

\section{RESULTS}

The total viable bacterial count (TVBC) of the fish samples varied from $8.8 \times 10^{8}$ to $1.27 \times 10^{8} \mathrm{cfu} / \mathrm{gm}$ and the average count of the five samples was $9.7 \times 10^{7} \mathrm{cfu} / \mathrm{gm}$. The highest TVBC was observed in the sample 1 and lowest in sample 5 (Fig. 1). The total staphylococcal count of the fish samples varied from $2.7 \times 10^{6}$ to $4.2 \times 10^{6} \mathrm{cfu} / \mathrm{gm}$ and the average count of the five samples was $3.6 \times 10^{6} \mathrm{cfu} / \mathrm{gm}$. The highest total staphylococcal count (TSC) was observed in the sample 1 and lowest in sample 5 (Fig. 1).

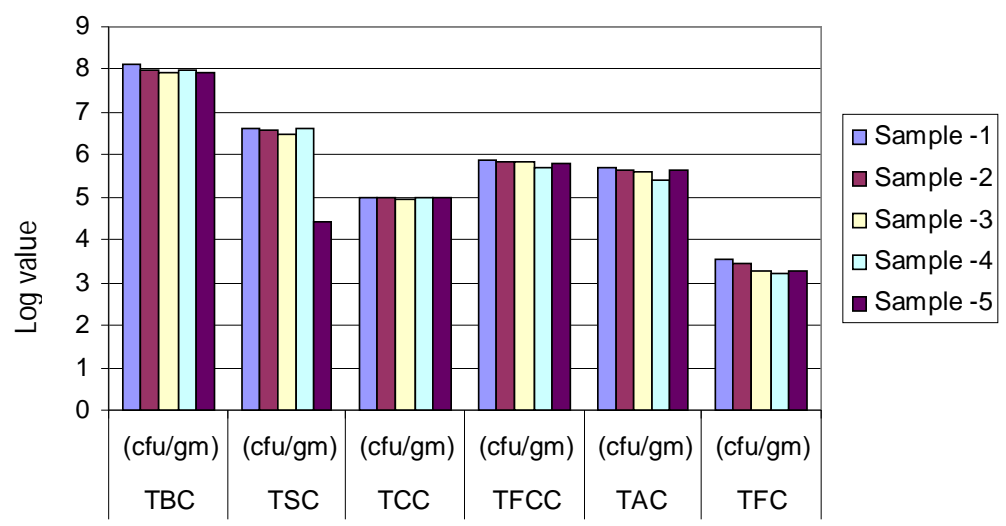

Fig. 1. Total count of associated microorganisms in freshwater mola fish.

The total coliform count (TCC) of the samples varied from $9.0 \times 10^{2}$ to $1.03 \times 10^{5}$ $\mathrm{cfu} / \mathrm{gm}$ and the average count of the five samples was $9.7 \times 10^{4} \mathrm{cfu} / \mathrm{gm}$. The highest total coliform count (TCC) was observed in the sample 2 and lowest in sample 3 (Fig. 3). The total faecal coliform counts (TCC) of the samples were varied from $4.810^{5} \mathrm{cfu} / \mathrm{gm}$ to 7.3 $\times 10^{5}$ and the average count of the five samples was $6.4 \times 10^{5} \mathrm{cfu} / \mathrm{gm}$. In case of total faecal coliform, the highest count was detected in the sample 1 and lowest was in sample 4. (Fig. 4). The total Aeromonas counts (TAC) were varied from $2.7 \times 10^{5}$ to $5.0 \times 10^{5}$ $\mathrm{cfu} / \mathrm{gm}$ and the average count of the five samples was $4.0 \times 10^{5} \mathrm{cfu} / \mathrm{gm}$. The highest TAC was observed in the sample 1 and lowest in sample 4 (Fig. 5). The total fungi count 
(TFC) of the fish samples varied from $1.6 \times 10^{3}$ to $3.5 \times 10^{3} \mathrm{cfu} / \mathrm{gm}$ and the average count of the five samples was $2.3 \times 10^{3} \mathrm{cfu} / \mathrm{gm}$. The highest TFC was observed in the sample 1 and lowest in sample 4 (Fig. 1).

Changes of the microbial count during frozen storage of fish samples were observed monthly. The initial total viable bacterial count (TVBC) was found to range from $8.8 \times 10^{7}$ to $1.27 \times 10^{8} \mathrm{cfu} / \mathrm{gm}$ and the average was $9.7 \times 10^{7} \mathrm{cfu} / \mathrm{gm}$ and after six months storage the average was $5.6 \times 10^{6} \mathrm{cfu} / \mathrm{gm}$ (Fig. 2). The initial total staphylococcal count (TSC) was ranged from $2.7 \times 10^{6}$ to $4.2 \times 10^{6} \mathrm{cfu} / \mathrm{gm}$, the average was $3.6 \times 10^{6} \mathrm{cfu} / \mathrm{gm}$ and after six months of storage the average count was $4.2 \times 10^{4} \mathrm{cfu} / \mathrm{gm}$ (Fig. 2). The initial total coliform count (TCC) ranged from $9.0 \times 10^{4}$ to $1.03 \times 10^{5} \mathrm{cfu} / \mathrm{gm}$, the average was $9.7 \times 10^{4} \mathrm{cfu} / \mathrm{gm}$ and after six months of storage its average was $6.8 \times 10^{3} \mathrm{cfu} / \mathrm{gm}$ (Fig. 2). The initial total faecal coliform count (TFCC) ranged from $4.8 \times 10^{5}$ to $7.3 \times 10^{5} \mathrm{cfu} / \mathrm{gm}$, the average was 6.4 $\times 10^{5} \mathrm{cfu} / \mathrm{gm}$ and after six months of storage the average was $5.2 \times 10^{4} \mathrm{cfu} / \mathrm{gm}$ (Fig. 2). The initial total Aeromonas count (TAC) ranged from $2.7 \times 10^{5}$ to $5.0 \times 10^{5} \mathrm{cfu} / \mathrm{gm}$, the average was $4.0 \times 10^{5} \mathrm{cfu} / \mathrm{gm}$ and after six months of storage the average was $3.8 \times 10^{4} \mathrm{cfu} / \mathrm{gm}$ (Fig. 2). The initial total fungi count (TFC) ranged from $1.6 \times 10^{3}$ to $3.5 \times 10^{3} \mathrm{cfu} / \mathrm{gm}$, the average was $2.3 \times 10^{3} \mathrm{cfu} / \mathrm{gm}$ and after six month of storage the total fungi count was nil. The fungus count of all the fish samples decreased gradually and after two months the count was nil in all the samples. So, it has been found that during frozen storage, the bacterial count was gradually decreased in all the samples (Fig. 3).

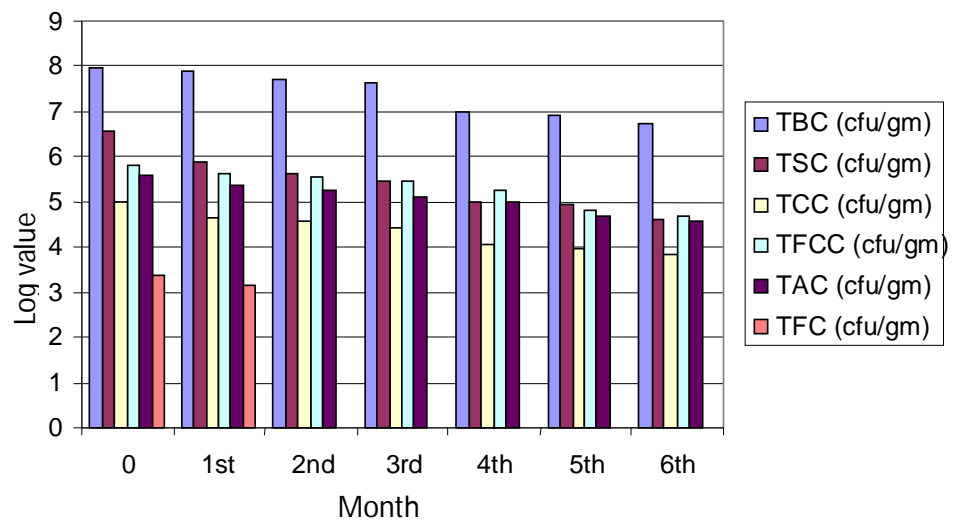

Fig. 2. Storage effect $\left(-20^{\circ} \mathrm{C}\right)$ on associated microorganisms in fresh water mola fish.

In the non-irradiated samples the average of total viable bacterial count (TVBC) was $9.7 \times 10^{7} \mathrm{cfu} / \mathrm{gm}$ and at the irradiation doses of 2.5 and $5.0 \mathrm{kGy}$, the count decreased to $4.5 \times 10^{3} \mathrm{cfu} / \mathrm{gm}$ and $3.4 \times 10^{3}$, respectively. The count was nil at the irradiation doses of $7.5 \mathrm{kGy}$ and $10.0 \mathrm{kGy}$. In the non-irradiated samples, total staphylococcal count (TSC) was $3.6 \times 10^{6} \mathrm{cfu} / \mathrm{gm}$. The count decreased to $5.2 \times 10^{4}$ and $4.1 \times 10^{3} \mathrm{cfu} / \mathrm{gm}$ at the irradiation doses of 2.5 and $5.0 \mathrm{kGy}$, respectively. At the irradiation doses of 7.5 and 10 
kGy, no count was observed (Fig. 3). Total coliform count (TCC) was $9.7 \times 10^{4} \mathrm{cfu} / \mathrm{gm}$ at the non-irradiated samples. At the irradiation doses of 2.5, 5.0, 7.5 and $10.0 \mathrm{kGy}$, the count was nil in all the samples (Fig. 3). In case of faecal coliform, it has been found that in the non-irradiated samples total faecal coliform count (TFCC) was $6.4 \times 10^{5} \mathrm{cfu} / \mathrm{gm}$. At the irradiation doses of 2.5, 5.0, 7.5 and $10.0 \mathrm{kGy}$, the count decreased to nil (Fig. 3). In non-irradiated samples the total Aeromonas count (TAC) was $4.0 \times 10^{5}$ and at the irradiation doses of 2.5, 5.0, 7.5 and $10.0 \mathrm{kGy}$, the count decreased to nil. In nonirradiated samples the total fungus count (TFC) was $2.3 \times 10^{3}$. At the irradiation doses of 2.5, 5.0, 7.5 and $10.0 \mathrm{kGy}$, the count decreased to nil (Fig. 3).

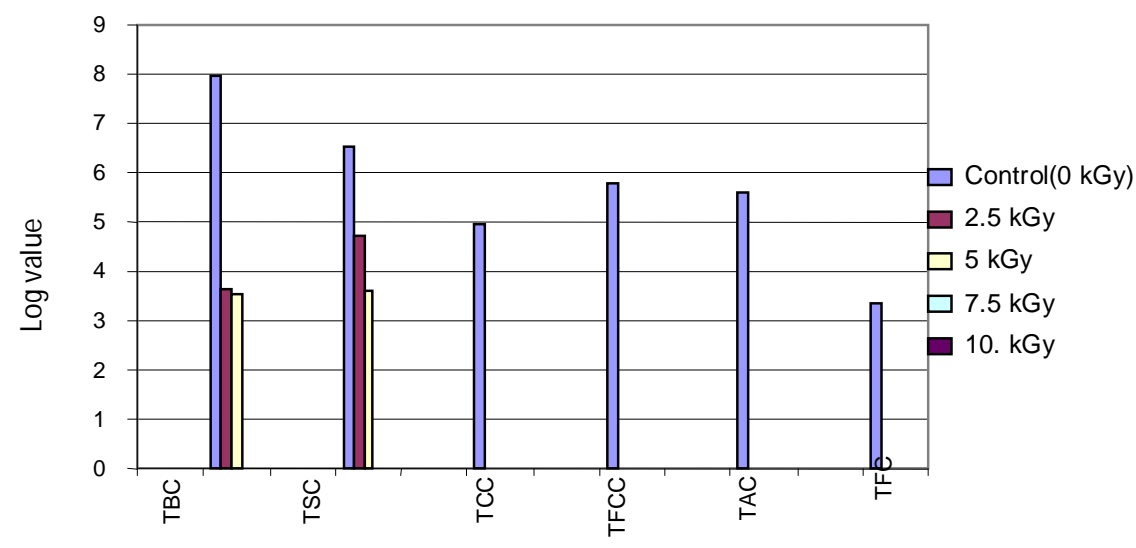

Fig. 3. Irradiation effect on microorganisms associated with fresh water mola fish.

In case of combined treatment (irradiation and low temperature storage), the fish samples were irradiated at $0 \mathrm{kGy}$ (control), 2, .5, 5.0, 7.5 and $10.0 \mathrm{kGy}$ of irradiation doses and then kept at $-20^{\circ} \mathrm{C}$ for six months and the microbial counts were observed in each month.

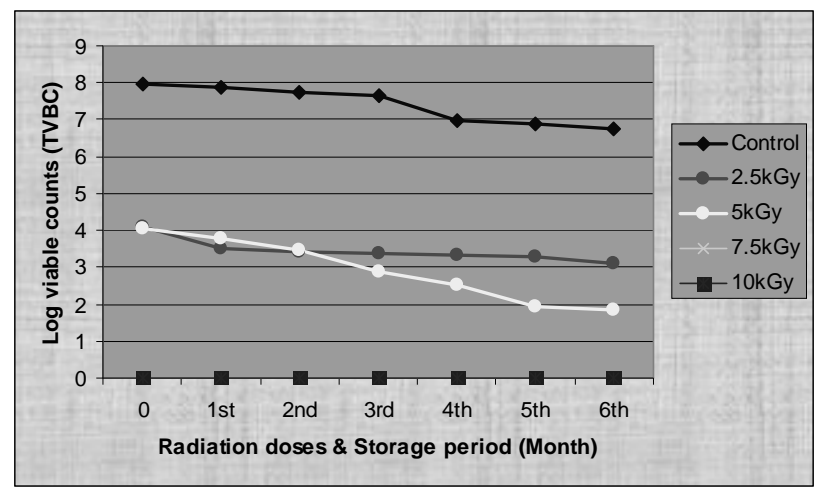

Fig. 4. Effects of combined treatment on total viable bacteria in fish samples. 
In case of total viable bacterial count (TVBC), the initial bacterial count at 0 month was $9.7 \times 10^{7} \mathrm{cfu} / \mathrm{gm}$. At the radiation doses of 2.5 and $5.0 \mathrm{kGy}$ in $0 \mathrm{month}$, the TVBC reduced to $1.3 \times 10^{4}$ and $1.1 \times 10^{4} \mathrm{cfu} / \mathrm{gm}$, respectively. Thus, no count was observed after the irradiation doses of 7.5 and $10 \mathrm{kGy}$ at the 0 month. After 1 month of frozen storage, the count of TVBC for control sample was $7.8 \times 10^{7}$. At the irradiation doses of 2.5 and $5.0 \mathrm{kGy}$, the reading decreased to $3.2 \times 10^{3}$ and $5.9 \times 10^{3} \mathrm{cfu} / \mathrm{gm}$, respectively. Similarly, after 2, 3, 4, 5 and 6 months of storage, control sample and at the irradiation doses of 2.5 and $5.0 \mathrm{kGy}$, the TVBC decreased to $5.6 \times 10^{7}, 4.3 \times 10^{7}, 9.9 \times 10^{6}, 7.9 \times$ $10^{6}, 5.6 \times 10^{6}$ and $2.7 \times 10^{3}, 2.4 \times 10^{3}, 2.1 \times 10^{3}, 1.9 \times 10^{3}, 1.3 \times 10^{3}$ and $3.0 \times 10^{3}, 7.6 \times$ $10^{2}, 3.4 \times 10^{2}, 8.8 \times 10^{1} \mathrm{cfu} / \mathrm{gm}, 6.7 \times 10^{1} \mathrm{cfu} / \mathrm{gm}$, respectively (Fig. 4). In case of total staphylococcal count (TSC), the total staphylococcal count at first month was $3.6 \times 10^{6}$ $\mathrm{cfu} / \mathrm{gm}$.

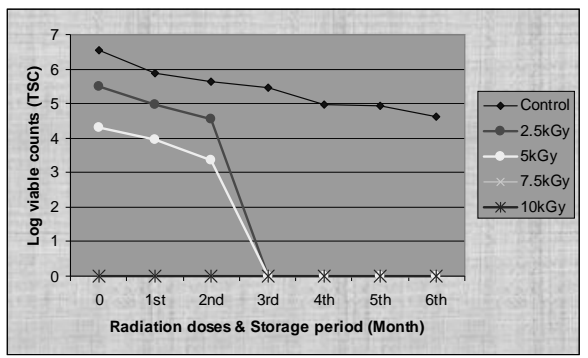

Fig. 5. Effect of combined treatment on total staphylococci bacteria in fish samples.

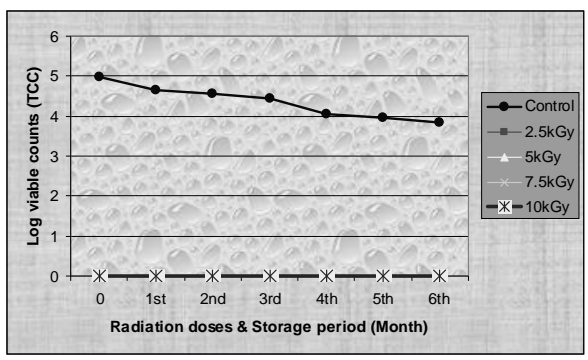

Fig. 6. Effect of combined treatment on total coliform bacteria in the fish samples.

At the radiation doses of 2.5 and $5.0 \mathrm{kGy}$, at the 0 month, the count reduced to $3.1 \times$ $10^{5}$ and $2.1 \times 10^{4} \mathrm{cfu} / \mathrm{gm}$, respectively. After first month of frozen storage, count of TSC for control sample was $7.8 \times 10^{5}$ and at the irradiation doses of 2.5 and $5.0 \mathrm{kGy}$, the count decreased to $9.7 \times 10^{4}$ and $7.3 \times 10^{3} \mathrm{cfu} / \mathrm{gm}$, respectively. After two months of frozen storage, count of TSC for control sample was $4.2 \times 10^{5} \mathrm{cfu} / \mathrm{gm}$ and at the irradiation doses of 2.5 and $5.0 \mathrm{kGy}$, the count decreased to $3.6 \times 10^{4} \mathrm{cfu} / \mathrm{gm}$ and $3.1 \times 10^{3} \mathrm{cfu} / \mathrm{gm}$, respectively. Similarly, after 3, 4, 5 and 6 months of storage, the count of total staphylococcal in control sample decreased to $2.9 \times 10^{5}, 9.4 \times 10^{4}, 8.8 \times 10^{4}$ and $4.2 \times 10^{4}$ cfu/gm, respectively. No count was observed at the irradiation doses of 2.5 and $5.0 \mathrm{kGy}$ in case of 4, 5 and 6th month. Similarly, at the irradiation doses of 7.5 and $10.0 \mathrm{kGy}$ in all months, the count was nil (Fig. 5). In case of combined treatment, initial total coliform count (TCC) was $9.7 \times 10^{4} \mathrm{cfu} / \mathrm{gm}$ in the non-irradiated samples whereas the samples, irradiated with 2.5, 5.0, 7.5 and $1.0 \mathrm{kGy}$, all counts were nil for every month (Fig. 6). In case of faecal coliform, in the non-irradiated samples the initial total faecal coliform count (TFCC) was $6.4 \times 10^{5} \mathrm{cfu} / \mathrm{gm}$ in the $1 \mathrm{st}$ month, whereas the samples irradiated with 2.5, 5.0, 7.5 and $1.0 \mathrm{kGy}$ all counts were nil for every month (Fig. 7). In case total 
Areomonas count (TAC), at first month of storage in the non-irradiated samples initial total Areomonas count (TAC) was $4.0 \times 10^{5} \mathrm{cfu} / \mathrm{gm}$ whereas the samples irradiated with 2.5, 5.0, 7.5, $1.0 \mathrm{kGy}$ there was none (Fig. 8).

In case of total fungi count (TFC), at the first month of storage in the non-irradiated samples initial total fungi count (TFC) was $2.3 \times 10^{3} \mathrm{cfu} / \mathrm{gm}$, whereas the samples irradiated with 2.5, 5.0, 7.5, $1.0 \mathrm{kGy}$ all counts were nil for every month (Fig. 9 ).

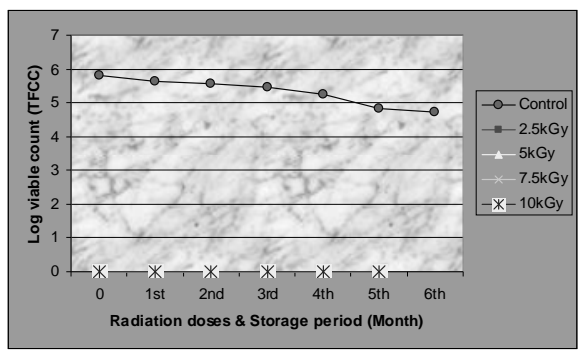

Fig. 7. Effects of combined treatment on total faecal coliform bacteria in fish samples.

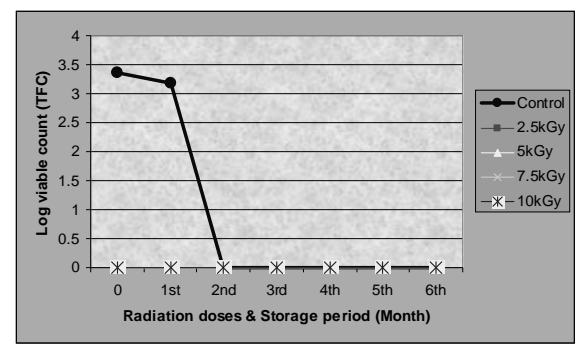

Fig. 9. Effects of combined treatment on total fungi in fish samples.

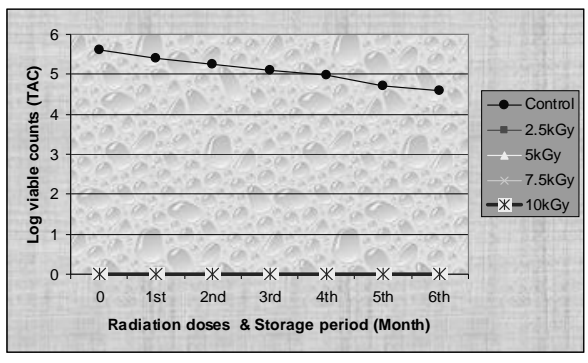

Fig. 8. Effects of combined treatment on total Aerumonas bacteria in fish samples.

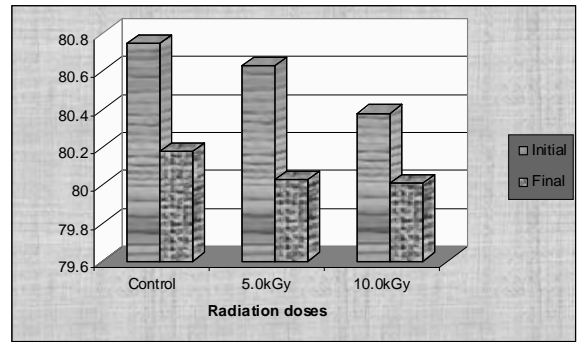

Fig. 10. Changes in moisture content of nonirradiated and irradiated samples.

Initially the bacteria which were associated with the fish samples were Staphylococcus aureus, Micrococcus varians, Klebsiella ozaenae, Bacillus subtilis, Escherichia coli, Bacillus megaterium, Klebsiella edwardsii, Pseudomonas aerugenosa, Aeromonas hydrophilla and Micrococcus radiodurans, but after six months of storage Klebsiella edwardsi and Micrococcus radiodurans became eliminated. According to Bergeys Mannual of Determinative Bacteriology (Bauman and Schuber 1984), there were 76 identified strains of which strain No. 101, 104, 113, 202, 206, 208, 302, 303, 401, 403, 410, 412, 501, 503, 602 and 603 were identified as Staphylococcus aureus, 102, 201 and 304 were Micrococcus radioduran, 103, 203, 207, 305, 402, 411, 413, 502, 504, 505 and 601 were Micrococcus varians, 106, 209, 210, 309, 405, 406, 508, 509 and 609 were Aeromonas hydrophila, 109, 213, 311, 407, 511 and 608 were Klebsiella, 108, 211, 306, 408, 506 and 607 were Bacillus subtilis, 110, 111, 307, 409, 512 and 605 were Bacillus, 
107, 112, 205, 301, 312, 414, 507 and 606 were Escherichia coli, 115, 214, 310 and 404 were Klebsiella and strain No. 105, 114, 204, 212, 308, 510 and 604 were identified as Pseudomonas aerugenosa.

The changes in moisture content (gm \%) of non-irradiated and irradiated samples have been shown in figures. The initial moisture content of the fish sample (control) was $80.75 \mathrm{gm} \%$. After six months of storage the final moisture contents was $80.18 \mathrm{gm} \%$, whereas in $5.0 \mathrm{kGy}$ irradiated samples the initial value was $80.63 \mathrm{gm} \%$, which decreases slightly during storage and finally the value was $80.03 \mathrm{gm} \%$. Incase of $10.0 \mathrm{kGy}$ irradiated samples, the initial value was $80.38 \mathrm{gm} \%$ which decreased slightly during storage period and finally the value was $80.01 \mathrm{gm}$ samples in low temperature.

The changes in protein content (gm \%) of non-irradiated and irradiated fresh water mola fish samples have been shown in Fig. 10. The initial protein content of the fish sample (control) was $21.89 \mathrm{gm} \%$ which decreased during storage and after six months of storage the final moisture contents was $17.87 \mathrm{gm} \%$, whereas in $5.0 \mathrm{kGy}$ irradiated samples the initial value was $21.65 \mathrm{gm} \%$ which also decreased during storage and finally the value was $17.53 \mathrm{gm} \%$. In case of $10.0 \mathrm{kGy}$ irradiated samples, the initial value was $21.47 \mathrm{gm} \%$ which decreased to $17.76 \mathrm{gm} \%$ in final storage time. For all of the samples the initial and final counts were slightly higher in non-irradiated samples compared to irradiated samples (Fig. 11).

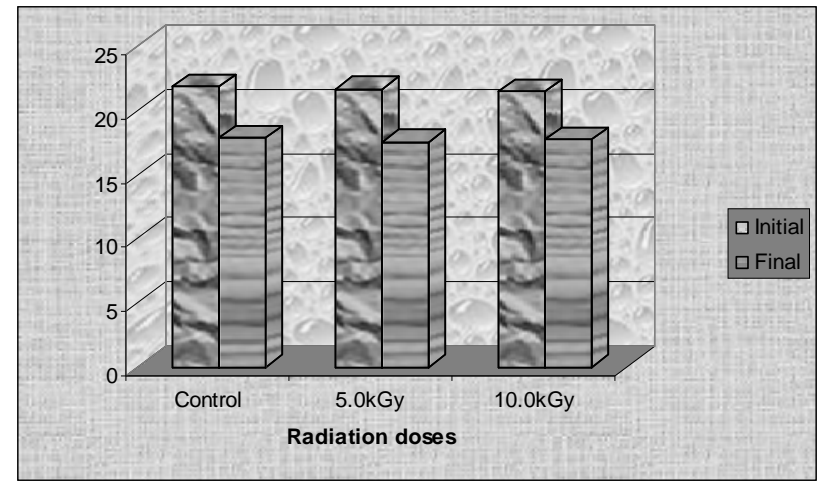

Fig. 11. Changes in protein content of non-irradiated and irradiated samples in low temperature.

\section{DISCUSSIONS}

In the present investigation, the total viable bacterial count (TVBC) of the sample varied from $8.8 \times 10^{7}$ to $1.27 \times 10^{8} \mathrm{cfu} / \mathrm{gm}$. The highest TVBC in sample 1 was $1.27 \times$ $10^{7}$. Similar results have been reported by Cho et al. (1992) and Ito et al. (1984). The 
total staphylococcal count (TSC) varied from $2.7 \times 10^{6}$ to $4.2 \times 10^{6} \mathrm{cfu} / \mathrm{gm}$ in the present study. Presence of Staphylococcus sp. suggests that there was higher level of environmental contamination and its presence indicates the possible risks of food poisoning as found by (Nanu and Narayan 1992). Total coliform counts (TCC) in the sample varied from $9.0 \times 10^{5}$ to $1.03 \times 10^{5} \mathrm{cfu} / \mathrm{gm}$ of the sample. Presence of coliform in food has been linked with the practice of inadequate hygienic measure, mishandling, improper storage and use of dirty water during marketing and all unhygienic condition of the shops (Munce 1980). This finding is supported by Rashid et al. (1996). The total Aeromonas count (TAC) varied from $2.7 \times 10^{5}$ to $5.0 \times 10^{5} \mathrm{cfu} / \mathrm{gm}$ in the present study which was similar to the finding of Cho et al. (1992) and Ito et al. (1984). Total faecal coliform counts (TFCC) varied from $4.8 \times 10^{5}$ to $7.3 \times 10^{5} \mathrm{cfu} / \mathrm{gm}$ in the present study which is similar to the findings of Munce (1980).

The result regarding isolated strains of bacteria in the present study is supported by several workers such as Islam et al. (2001), Anwar et al. (1988), Jay (1977), Banwart (1979), Dyer (1942), Liston (1960) and Shewan and Hobbs (1967), Lee and Pfeifer (1977), Burke et al. (1983), Clark and Pegel (1977). Anwar et al. (1988) reported that freezing reduced bacterial load of shrimps which is more or less similar to the findings of present study. Total Aeromonas count (TAC) decreased gradually from initial to final storage period in all the samples. Similar results have been reported by Anwar et al. (1988). Total viable bacterial count (TVBC) was reduced one to two-folds at 2.5, 5.0 kGy of irradiation doses and become nil after the radiation doses of $7.5 \mathrm{kGy}$. The result is supported by Ito et al. (1993) and Khatun et al. (1996). Total Staphylococcal count (TSC) became reduced at 2.5 and $5.0 \mathrm{kGy}$ of irradiation doses and became nil at the radiation doses of $7.5 \mathrm{kGy}$ which is similar to the findings of Ito et al. (1993) and Hossain et al. (1979). Total coliform count (TCC), total faecal coliform count (TFCC), total Aeromonas count (TAC) and total fungi count (TFC) decreased to nil at the radiation doses of 2.5 kGy which is similar to the data of Ito et al. (1993).

Bacteria survived after irradiation also gradually decreased during frozen storage, and after six months of storage it decreased about three to four log more in all the samples. Similar results have been reported by Thampuran and Gopakumar (1991) and Anwar et al. (1988). Brogstorm (1961) reported that the moisture contents in fresh fishes were 66 to $84 \%$. The present findings of biochemical compositions of mola fish were within of the range of the findings of that author. INFS (1980) reported that freshwater fishes contained 70 to $80 \%$ moisture which supports the present findings. Initially total protein value of control $(0 \mathrm{kGy})$ mola fish samples was $21.89 \%$ which is within the findings of Brogstorm (1961) and Rubbi et al. (1987). 


\section{REFERENCES}

Anwar, M. N., S. B. Shah and M. S. A. Khan. 1988. Effect to freezing and frozen storage on the faecal indicator organisms in shrimp. Bangladesh J. Bot. 17(1): 95-97.

Banwart, J. 1979. Basic Food Microbiology (2nd ed.). CBS Publishers and Distributors, Delhi, India. pp. 218-225, 549-595, 601-603.

Brogstorm, G. 1961. Fish as Food (Vol. 1). Academic Press, Inc., New York, USA.

Baumann, P. and R.H.W. Schubert. 1984. Family II. Vibrionaceae veron 1965, 5245, pp. 516-550. In: N.R. Krieg and J.G. Holt (ed). Bergey' Manual of Determinative Bacteriology, Vol. 1. The Williams and Wilkins Co., Baltimore, USA.

Burke, V., M. Gracey, J. Robinson, D. Peck, J. Beaman and C. Bundell. 1983. The microbiology of childhood gastroenteritis. Aeromonas species and other infective agents. J. Infect Dis. 148:68-74.

Cho, H.O., M.N. Byun and J.K. Known. 1992. Preservation of dried fish by Gamma irradiation. Division of food irradiation, Korea Advanced Energy Research Institute, Seul, Korea. IAEA-RC-341/4.

Clark, J.A. and J.E. Pegel. 1977. Pollution indicator bacteria associated with municipal raw and drinking water supplies. Can. J. Microbial. 23: 465-470.

Dyer, W. J. 1942. The salting of codfish. Prog. Rep. Atant. Cst. Stns. 32: 6.

Frazier, W. C. and D. C. Westhoff. 1988. Food Microbiology (4th ed.). McGraw-Hill Book Co. Singapore. pp. 83-84, 143-154, 167, 212-250.

Hobbs, B.C. 1982. Food microbiology, Arnold-Hein Mann, New Delhi.

Islam, M.A., A.R. Khan, H. Rashid, S.M. Asaduzzaman and N. Choudhury. 2001. Microbial spoilage of dried lotia fish (Harpodon neherius) and their preservation by radiation. Bangladesh J. Microbial. 18(1): 67-72.

Ito, H., H. O. Rashid, N. Sangthong, P. Adulyatham, P. Ratagool and I. Ishijaki. 1993. Effects of gamma irradiation on frozen shrimp for decontamination of pathogenic bacteria. Radiat. Phys. Chem. 42(1-3): 279-282.

Ito, H. and M.A. Yusup. 1984. Study of microflora in Malaysian dried fish and their decontamination by Gamma irradiation. Faculty of Food Science and Technology, University of Agriculture, Serdan, Malaysia.

Jay, J.M. 1977. Meats, poultry and sea foods. In: Food and Beverage and Mycology, $5^{\text {th }}$ edn., L.R. Beuchat, Westport, Conn. AVI.

Khatun, M., N. Banu, M. M. Hossain and A. Hossain. 1996. Stability of irradiation in Kakila. Xenentodon cancila (Ham) at different storage temperature. Bangladesh J. Zool. 24(2): 185-187.

Kreig, N.R. 1984. Bergey's Manual of Systematic Bacteriology. Baltimore, Williams and Wilkins Co. Vol. 1.

Lee, J. S. and K. K. Pfeifer. 1977. Microbiological charcteristics of Pacific shrimp (Pandalus jordani). Appl. and Environ. Microbiol. 33(4): 853-856.

Liston, J. 1960. The bacterial flora of fish caught in the Pacific. J. Appl. Bacteriol. 23: 469-470. 
Munce, H. R. 1980. Principles of food packaging - an international guide/FAO, United Nation. pp. 19-21.

Rahman, A.K.A. 2005. Freshwater fishes of Bangladesh. Published by Zoological Society of Bangladesh, Department of Zoology, University of Dhaka, Dhaka-1000, Bangladesh. Second edition. pp. 122-123.

Rashid, H., M. R. Khan and N. Chowdhury. 1996. Microbiologycal aspects of frozen fish irradiation. IFRB. AERE, Savar. Dhaka. Bangladesh Journal of Microbiology 13: (1 \& 2). pp. 83-88.

Rubbi, S. F., M. M. Rahman, A. R. Khan, S. S. Jahan and M. Begum. 1987. Proximate composition and quality of some commercial species of fresh water fish. Bang. $J$. Sci. Res. 5(1): 1-20.

Sharp, M. S. and S. T. Lyles. 1969. Laboratory Instructions in Biology of Microorganisms. St. Louis. The C. V. Masby Company. pp. 23-25.

Shewan J. M. and G. Hobbs. 1967. Effects of freezing on the spoilage flora of fishery products. In: Processing in Industrial Microbiology. 6. D. D. D. Hocheahull (ed.): Life Books London.

Thampuran, N. and K. Gopakurmar. 1991. Microbial profile of tropical prawn (Metapenaeus dobsoni) during frozen storage. J. Food Science and Technology. India. 28(6): 371-374.

Thomson, W. K. and C. L. Thacker. 1973. Effects of temperature on Vibrio parahaemolyticus in oysters at refrigerator and deep freeze temperatures. Can. Inst. Food Sci. Technol. J. 6: 156-158.

(Received revised manuscript on 11 February, 2013) 